Review Article:

\title{
Evaluation of Maternal Risk Factors, Delivery, and Neonatal Outcomes of Premature Rupture of Membrane: A Systematic Review Study
}

\author{
Hassan Boskabadi $^{1}$ (D), Maryam Zakerihamidi2* (D)
}

1. Department of Pediatrics, School of Medicine, Mashhad University of Medical Sciences, Mashhad, Iran.

2. Department of Midwifery, School of Medical Sciences, Tonekabon Branch, Islamic Azad University, Tonekabon, Iran.

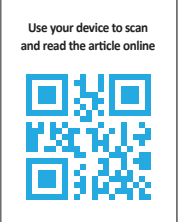

ditation: Boskabadi H, Zakerihamidi M. Evaluation of Maternal Risk Factors, Delivery, and Neonatal Outcomes of Premature Rupture of Membrane: A Systematic Review Study. Journal of Pediatrics Review. 2019; 7(2):77-88. http://dx.doi.org/10.32598/jpr.7.2.77

:http://dx.doi.org/10.32598/jpr.7.2.77

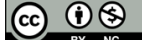

Funding: See Page 86

Article info:

Received: 20 February 2018

First Revision: 15 March 2018

Accepted: 05 May 2018

Published: 01 April 2019

\section{Keywords:}

Premature rupture of membrane, Risk factors, Neonatal, Maternal, Complication

\begin{abstract}
Context: Premature rupture of membrane is a serious complication in pregnancy and responsible for one third of preterm labors associated with the neonatal and delivery outcomes.

Objective: The current study aimed at investigating the risk factors of premature rupture of membrane on delivery and neonatal implications.

Data Sources: The articles on the databases, including PubMed, Cochrane Library, ISI and Google Scholar up to 2017 were searched to conduct the current study. The keywords used were "premature rupture of membrane", "neonatal," "risk factors", "maternal”, and "delivery".

Study Selection: The inclusion criteria were articles on the relationship between maternal risk factors and Premature Rupture of Membrane (PROM), neonatal outcomes of PROM, the delivery outcomes of PROM, the study of mothers and infants, English and Persian language articles, and sufficient information on the PROM. The articles investigating amniotomy or the ones that only their abstracts were available were excluded from the study.

Data Extraction: The data extracted from the above mentioned databases were fed with the following titles in the Excel software: Authors' names and surnames, year of study, type of study, place of study, case group, control group, maternal risk factors, delivery outcomes, neonatal outcomes of PROM, and the results of the study.

Results: Out of 90 articles, 15 articles were finalized including one prospective study, five crosssectional papers, six retrospective articles, and three historical cohort studies. Maternal risk factors included age; parity; education; occupation; diabetes; blood pressure; cervical length along with abortion history; history of infection, upper urinary tract infection, and sexually transmitted diseases. Moreover, delivery complications were cesarean section, oligohydramnios, chorioamnionitis, and placental abruption. Neonatal complications included prematurity, respiratory distress syndrome, asphyxia, infection, meningitis, sepsis, pneumonia, perinatal mortality, patent arterial duct, necrotizing enterocolitis, IVH, pulmonary hypoplasia, hyperbilirubinemia, and antibiotic intake.
\end{abstract}

Conclusions: Based on the results of the current study, the most important risk factors for PROM were diabetes and maternal hypertension associated with neonatal and maternal complications. Infection was the most important maternal and neonatal complication.

\section{* Corresponding Author:}

Maryam Zakerihamidi, PhD.

Address: Department of Midwifery, School of Medical Sciences, Tonekabon Branch, Islamic Azad University, Tonekabon, Iran.

Tel: +98 (911) 3934386

E-mail: maryamzakerihamidi@yahoo.co.nz 


\section{Context}

remature Rupture of Membrane (PROM) refers to rupture of membrane before the onset of labor pain in pregnancies less than 37 weeks (1). PROM occurs in $3 \%$ to $8 \%$ of pregnancies and causes one third of premature labors (2). In the case of membrane rupture, if the risk of an increased infection prevails over the risk of prematurity, delivery is recommended to be performed (1). A prolonged premature rupture of membrane refers to the premature rupture of membrane for more than 18 hours associated with increased risk (up to 10 times) of neonatal infections (3).

The prevalence of PROM varies in different countries and populations, and many factors affect its occurrence. Therefore, its etiology is complex and multifactorial. Two-thirds of PROM cases occur spontaneously or for unknown reasons (4). However, other cases are due to structural defects in the membrane due to deficiency of collagen content in the membrane, protrusion of the membrane due to isthmus-cervical incompetence, and activation of catabolic enzymes such as collagenase, the fetal membranes weakens due to enzymatic degeneration in inflammatory or infectious processes, mechanical stresses $(1,5,6)$, and secretion of proteoIytic enzymes from cervicovaginal flora or infectious of amniotic fluids (7).

One of the main causes of the PROM occurrence is infection (often bacterial infection) that stimulates the release of proinflammatory cytokines from decidua and amniotic membranes. Therefore, many bioactive materials, such as prostaglandins and metalloproteases are released. Prostaglandins stimulate uterine contractions, and metalloproteases cause cervical ripening, and ultimately cause the rupture of membrane (8).

The risk factors for PROM include maternal ones, including the history of PROM in previous pregnancies (the risk of recurrence of $16 \%$ to $32 \%$ in comparison with the risk of $4 \%$ in non-complicated term pregnancies), vaginal bleeding before delivery, long-term use of steroids, vascular collagen disorders such as EhlersDanlos syndrome, systemic lupus erythematosus, abdominal trauma, preterm labor history, cigarette smoking, drug abuse, anemia, low BMI (under $19.8 \mathrm{~kg} / \mathrm{m} 2$ ), food deficiencies including ascorbic acid and copper, low socioeconomic status (9), history of hypertension, abortion, cesarean section (10), black race/ethnicity, access to hospital care services, marital status, parity, history of preterm labor, exposure to diethylstilbestrol in the uterus. Other risk factors in this group are related to pregnancy complications such as gestational diabetes or overt diabetes, maternal weight gain, diagnostic procedures such as cerclage and amniocentesis (6).

There are other related factors such as mother age less than 20 and over 35 years, blood group, gravidity, pelvic stenosis, maternal fatigue during work (11), lack of treatment during pregnancy, sexually transmitted infections (12), history of cervical surgery, genital infections (chorioamnionitis or mycoplasma or chlamydia accumulation); and maternal diseases (pulmonary, hypertension, and diabetes) (13).

Uterine-placental risk factors include uterine abnormalities (such as uterine septum), placental abruption (may cause $10 \%$ to $15 \%$ of premature rupture of the membrane), cervical failure, previous cervical conization, cervical shortening in the second trimester (below 2.5 $\mathrm{cm}$ ), excessive dilation of the uterus (polyhydramnios, multiple pregnancy), chorioamnionitis, vaginal examinations (with non-sterile speculum or vaginal ultrasonography), cervical cerclage, and abnormal vaginal discharge $(9,10)$. Neonatal risk factors include multiple pregnancies (premature rupture of the membranes complicated $7 \%-10 \%$ of twin pregnancies) (9), inappropriate position of the fetus (11), and high birth weight (12).

The premature rupture of the membrane presents $2 \%$ to $20 \%$ of delivery complication and is associated with $18 \%$ to $20 \%$ of perinatal deaths (1). PPROM is associated with many neonatal complications, including respiratory distress syndrome, neonatal sepsis, and fetal death. The most common maternal complication of PPROM is infection. Chorioamnionitis occurs in $13 \%$ to $60 \%$ of pregnant mothers and postpartum infection or endometritis in $2 \%$ to $13 \%$ of mothers (6). Maternal complications of PROM include severe bacterial infection $(0.8 \%)$ that can lead to maternal death $(0.14 \%)$, increased cesarean sections, placental abruption ( $9 \%$ to $12 \%)$, disseminated intravascular coagulation, sepsis, endometritis ( $2 \%$ to $13 \%)$, Asherman syndrome, menstruation delay (14-16), cervical incompetence, labor disorder, and postpartum hemorrhage (17).

Fetus complications include perinatal infection, cord compression due to oligohydramnios (15), hyaline membrane disease, intraventricular hemorrhage, sepsis, umbilical cord prolapse, fetal distress, and increased fetal death. Prolonged rupture of the membrane is associated with an increased risk of infection and chorioamnionitis, which increases the incidence of cesarean section (17). 
Since the exact cause of the PROM is unclear, there is no effective method to prevent it. On the other hand, considering the importance of PROM for the delivery, maternal and neonatal outcomes, the early identification of risk factors for PROM and their control can reduce the occurrence of maternal and neonatal outcomes of PROM and promote the health of mothers and neonates.

\section{Objective}

The current study aimed at systematically reviewing the risk factors and outcomes of premature rupture of the membrane.

\section{Data Sources}

After a preliminary review of the articles, a list of risk factors and the outcomes of the premature rupture of the membrane were provided for the systematic review, and articles that only examined maternal risk factors for the premature rupture of membrane, as well as maternal and neonatal outcomes were studied. In this regard, articles containing maternal risk factors, delivery outcomes, neonatal outcomes, or a combination of them were included.

The PubMed, Embrase, and Google Scholar databases were used to conduct systematic reviews and find studies including maternal risk factors, delivery outcomes, and neonatal outcomes of PROM. To search the articles, the keywords "PROM", "Risk Factors", and "Outcome" were used. There were 90 studies that had the inclusion criteria and were collected using the EndNote software in a separate library file. Of these, 40 duplicate articles were eliminated. The articles were evaluated regarding their titles and abstracts and 30 articles were eliminated at this stage. Of the remaining 20 papers, five papers were omitted due to incomplete data, the absence of full text, the uncertainty of the type of study, and the target group. Finally, 15 articles related to the study topic were included.

\section{Study Selection}

\subsection{Inclusion criteria}

Articles were selected based on the following criteria: 1 . The population of study were neonates or mothers; 2 . Premature rupture of the membrane was confirmed; 3. Maternal risk factors of premature rupture of the Membrane were evaluated; 4 . Neonatal outcomes of the premature rupture of the membrane were evaluated; 5. Articles were in the English and Persian languages; and 6 . There was sufficient information about the condition of the premature rupture of the membrane.

\subsection{Exclusion criteria}

The following articles were excluded from the study due to irrelevancy: 1 . Articles reviewing amniotomy; 2. Articles examining factors other than maternal risk factors; 3 . Articles not addressing the neonatal outcomes; and 4. Articles without full texts.

\section{Data Extraction}

Articles with full text from the above mentioned databases were downloaded. The data extracted from them were fed with the following titles into the Excel software: authors' names and surnames, year of study, type of study, place of study, case group, control group, maternal risk factors, delivery outcomes, neonatal outcomes of PROM, and the results of the study. Of the 100 papers found, 15 papers with a sample size of 3225 neonates were finally examined. The articles were from 1997 to 2017. Four articles (26.66\%) reviewed the maternal risk factors and one $(6.67 \%)$ article reviewed the delivery outcomes, one article (67.6\%) examined neonatal complications, and nine articles (60\%) dealt with the combination of these factors.

\section{Results}

\subsection{The prevalence of studies on the risk factors and outcomes of PROM}

A review of related studies conducted from 1997 to 2017 showed that most studies examined the combination of risk factors, and maternal and delivery outcomes of PROM. Also, four studies examined maternal risk factors, one study investigated the delivery outcomes, and one study investigated neonatal outcomes of PROM.

\subsection{Controversies among the studies}

The studies on the risk factors and neonatal and delivery outcomes of PROM were different in terms of inclusion criteria, study population, case group definition, research methodology, sample size, and location. There were one prospective study, five crosssectional studies, six retrospective articles, and three historical cohorts (Table 1). 
6.3. Global distribution of the studies on the risk factors and delivery and neonatal outcomes of PROM

Out of these reviewed articles four (26.66\%) were conducted in Iran, two studies (13.33\%) in the United States, two studies (13.33\%) in India, one study, one study (6.66\%) in Oman, one study (6.66\%) in Indonesia, one study $(6.66 \%)$ in Ireland, one study $(6.66 \%)$ in the
Netherlands, one study (6.66\%) in Canada, one study $(6.66 \%)$ in Brazil and one study (6.66\%) in Nigeria.

\subsection{Maternal risk factors for PROM (4 articles)}

In a case-control study, Saremi et al. (2012) investigated maternal risk factors including vaginal culture, abortion history, and cervical length on 121 subjects as

Table 1. Summary of the studies on maternal risk factors, delivery, and neonatal outcomes of PROM

\begin{tabular}{|c|c|c|c|c|c|c|c|}
\hline $\begin{array}{l}\text { Authors, } \\
\text { Study Year }\end{array}$ & Method & $\begin{array}{l}\text { Study } \\
\text { Area }\end{array}$ & $\begin{array}{l}\text { Case } \\
\text { Group }\end{array}$ & $\begin{array}{l}\text { Control } \\
\text { Group }\end{array}$ & $\begin{array}{l}\text { Maternal Risk } \\
\text { Factors }\end{array}$ & $\begin{array}{c}\text { Delivery } \\
\text { Outcomes }\end{array}$ & Neonatal Outcomes \\
\hline 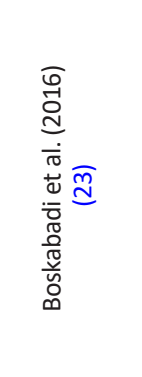 & $\begin{array}{l}\text { Cross- } \\
\text { sectional }\end{array}$ & Iran & 309 & nates & $\begin{array}{l}\text { Diabetes and } \\
\text { hypertension are } \\
\text { the most common } \\
\text { risk factors for the } \\
\text { prolonged rupture of } \\
\text { membrane }\end{array}$ & $\begin{array}{c}\text { Caesarean } \\
\text { section, oligo- } \\
\text { hydramnios, } \\
\text { chorioamnio- } \\
\text { nitis, placental } \\
\text { abruption, fetal } \\
\text { distress, fever } \\
\text { during labor } \\
\text { and placenta } \\
\text { previa were } \\
\text { complications } \\
\text { during labor. }\end{array}$ & $\begin{array}{l}\text { Prematurity, respiratory } \\
\text { problems, asphyxiation } \\
\text { and infection were } \\
\text { among the most serious } \\
\text { problems. }\end{array}$ \\
\hline
\end{tabular}
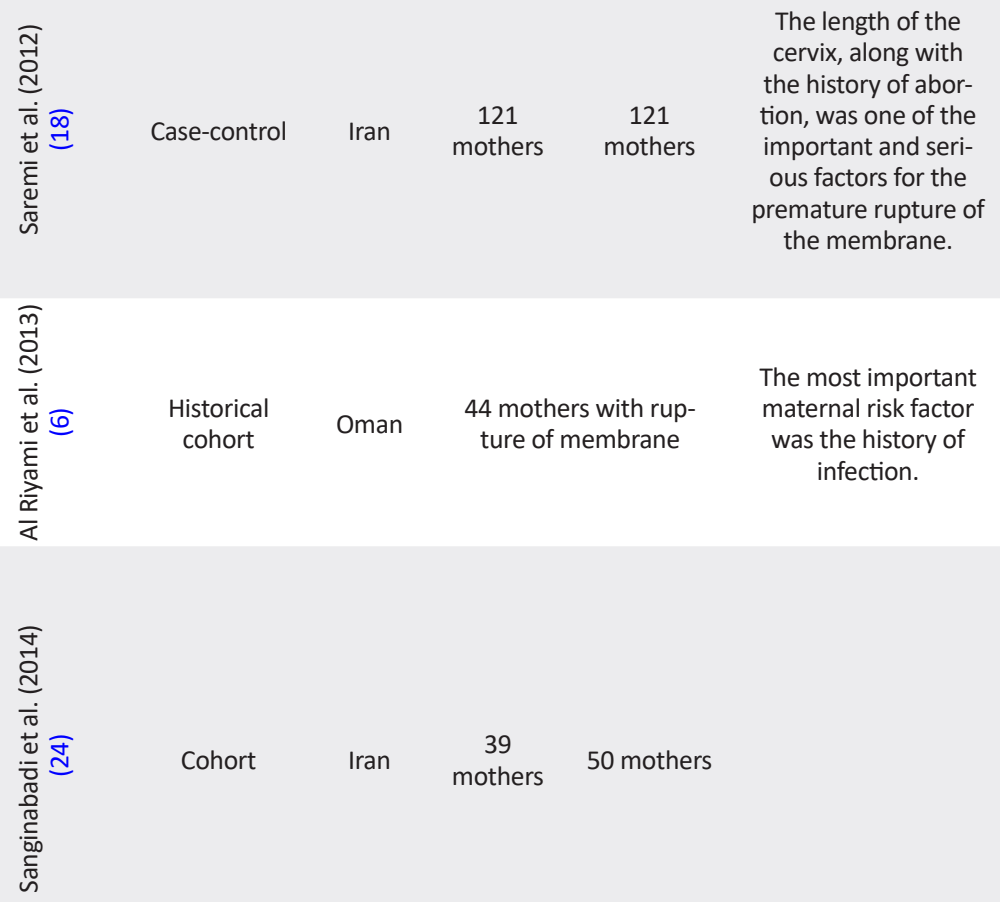

PROM caused infections (45\%), prenatal bleeding $(25 \%)$, and cesarean section $(27 \%)$

\begin{tabular}{|c|c|}
\hline $\begin{array}{l}\text { The mean age } \\
\text { of mothers, } \\
\text { the number of } \\
\text { pregnancies, } \\
\text { the frequency } \\
\text { of neonatal } \\
\text { death and } \\
\text { chorioamnion- } \\
\text { itis were signifi- } \\
\text { cantly higher in } \\
\text { the case group } \\
\text { than in the } \\
\text { control group. }\end{array}$ & $\begin{array}{l}\text { Mean weight, Apgar } \\
\text { score in the first and } \\
\text { fifth minutes, gestational } \\
\text { week at delivery, mean } \\
\text { time between PROM } \\
\text { and delivery and delivery } \\
\text { were significantly lower } \\
\text { in case group than the } \\
\text { control group. }\end{array}$ \\
\hline
\end{tabular}

Prematurity (67.3\%), respiratory distress syndrome (22.6\%), asphyxia $(8.6 \%)$, meningitis $(5.2 \%)$ sepsis (4\%), pneumonia (1.3\%), and death $4.6 \%)$. 


\begin{tabular}{|c|c|c|c|c|c|c|c|}
\hline $\begin{array}{l}\text { Authors, } \\
\text { Study Year }\end{array}$ & Method & $\begin{array}{l}\text { Study } \\
\text { Area }\end{array}$ & $\begin{array}{l}\text { Case } \\
\text { Group }\end{array}$ & $\begin{array}{l}\text { Control } \\
\text { Group }\end{array}$ & $\begin{array}{l}\text { Maternal Risk } \\
\text { Factors }\end{array}$ & $\begin{array}{l}\text { Delivery } \\
\text { Outcomes }\end{array}$ & Neonatal Outcomes \\
\hline 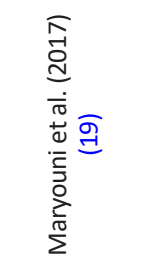 & Case-control & $\begin{array}{l}\text { Indo- } \\
\text { nesia }\end{array}$ & $\begin{array}{c}114 \\
\text { mothers } \\
\text { with pre- } \\
\text { mature } \\
\text { rupture } \\
\text { of mem- } \\
\text { brane }\end{array}$ & $\begin{array}{l}228 \text { moth- } \\
\text { ers without } \\
\text { premature } \\
\text { rupture of } \\
\text { membrane }\end{array}$ & $\begin{array}{l}\text { Age, parity and } \\
\text { education were risk } \\
\text { factors for PROM }\end{array}$ & & \\
\hline 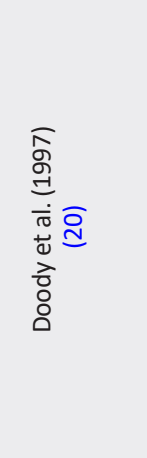 & Case-control & USA & $\begin{array}{l}208 \\
\text { mothers } \\
\text { with se- } \\
\text { quential } \\
\text { PROM }\end{array}$ & $\begin{array}{l}848 \text { moth- } \\
\text { ers with } \\
\text { one PROM } \\
\text { in the } \\
\text { previous } \\
\text { deliveries }\end{array}$ & $\begin{array}{l}\text { In mothers with } \\
\text { one PROM in the } \\
\text { previous deliveries, } \\
\text { increased risk of } \\
\text { recurrence of PROM } \\
\text { was associated with } \\
\text { fetal death below } 20 \\
\text { weeks of gestation } \\
\text { with parity of } 2 \text { or } \\
\text { more. No factor } \\
\text { increased the risk of } \\
\text { recurrence of PROM } \\
\text { in mothers with } \\
\text { PPROM history. }\end{array}$ & & \\
\hline 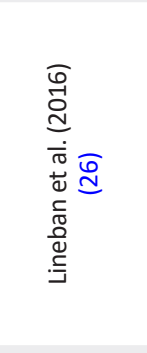 & $\begin{array}{l}\text { Cohort } \\
\text { descriptive } \\
\text { retrospective }\end{array}$ & Ireland & $\begin{array}{r}42 \text { case } \\
\text { prolonge } \\
\text { the seconc } \\
\text { pregnancy } \\
23 \text { weeks }\end{array}$ & $\begin{array}{l}\text { that had } \\
d \text { PROM in } \\
\text { trimester of } \\
\text { (14 weeks to } \\
\text { and } 6 \text { days). }\end{array}$ & & $\begin{array}{c}\text { Maternal } \\
\text { morbidity was } \\
\text { sepsis (2.4\%), } \\
\text { need for anti- } \\
\text { biotic therapy } \\
\text { (38\%), placen- } \\
\text { tal retention } \\
\text { (21\%), and } \\
\text { postpartum } \\
\text { hemorrhage } \\
\text { (12\%). }\end{array}$ & $\begin{array}{l}\text { Clinical chorioamnionitis } \\
\text { had a low prevalence } \\
(14 \%) \text {. Neonatal death } \\
\text { (77\%), RDS (70\%), } \\
\text { sepsis }(30 \%) \text {, necrotizing } \\
\text { enterocolitis (20\%) and } \\
\text { IVH (30\%), coagulase- } \\
\text { negative staphylococci } \\
\text { (20\%), patent artery } \\
\text { ducts (40\%). }\end{array}$ \\
\hline 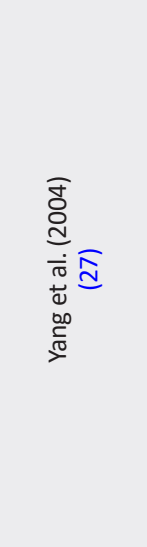 & $\begin{array}{l}\text { Retrospec- } \\
\text { tive }\end{array}$ & USA & $\begin{array}{r}73 \text { singlet } \\
\text { cies with } \\
26\end{array}$ & $\begin{array}{l}\text { Dn pregnan- } \\
\text { ROM (16 to } \\
\text { veeks) }\end{array}$ & & $\begin{array}{c}\text { Maternal mor- } \\
\text { bidity was low } \\
\text { and included } \\
\text { puerperal } \\
\text { endometritis } \\
(6.8 \%) \text {, which } \\
\text { caused septi- } \\
\text { cemia in one } \\
\text { person, which } \\
\text { did not leave } \\
\text { a long-time } \\
\text { complication. }\end{array}$ & $\begin{array}{l}\text { The prevalence of sepsis } \\
\text { was } 42.1 \% \text {, stillbirth rate } \\
\text { was } 30.1 \% \text { and neonatal } \\
\text { death was } 17.8 \% \text {, pul- } \\
\text { monary hypoplasia was } \\
15.7 \% \text {, and IVH grade } 3 \\
\text { or } 4 \text { was } 7.9 \% \text {. The risk } \\
\text { of neonatal pulmonary } \\
\text { hypoplasia was greater } \\
\text { than the gestational age } \\
\text { at the time of delivery } \\
\text { to the gestational age at } \\
\text { the time of the rupture } \\
\text { of membrane. Clinical } \\
\text { chorioamnionitis was } \\
37 \% \text { and histological cho- } \\
\text { rioamnionitis } 67.1 \% \text {. }\end{array}$ \\
\hline 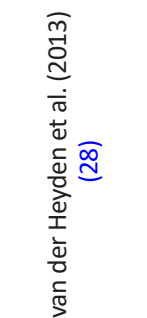 & $\begin{array}{l}\text { Retrospec- } \\
\text { tive cohort }\end{array}$ & $\begin{array}{l}\text { Neth- } \\
\text { erland }\end{array}$ & $\begin{array}{l}305 \text { preg! } \\
\text { PPROM be }\end{array}$ & $\begin{array}{l}\text { lancies with } \\
\text { ow } 27 \text { weeks }\end{array}$ & $\begin{array}{l}\text { Low gestational } \\
\text { age at PPROM } \\
\text { time, short interval } \\
\text { between PPROM and } \\
\text { delivery time, posi- } \\
\text { tive vaginal culture, } \\
\text { and no antibiotic use } \\
\text { at admission time }\end{array}$ & & $\begin{array}{l}\text { Perinatal mortality was } \\
49 \% \text {, and there were } \\
\text { serious complications of } \\
\text { PPROM in } 41 \% \text { of infants. }\end{array}$ \\
\hline
\end{tabular}




\begin{tabular}{|c|c|c|c|c|c|c|c|}
\hline $\begin{array}{l}\text { Authors, } \\
\text { Study Year }\end{array}$ & Method & $\begin{array}{l}\text { Study } \\
\text { Area }\end{array}$ & $\begin{array}{l}\text { Case } \\
\text { Group }\end{array}$ & $\begin{array}{l}\text { Control } \\
\text { Group }\end{array}$ & $\begin{array}{l}\text { Maternal Risk } \\
\text { Factors }\end{array}$ & $\begin{array}{l}\text { Delivery } \\
\text { Outcomes }\end{array}$ & Neonatal Outcomes \\
\hline 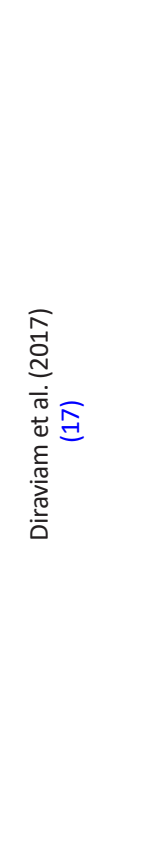 & Descriptive & India & $\begin{array}{r}141 \text { pre- } \\
\text { betweer } \\
36 \text { weel } \\
\text { wit }\end{array}$ & $\begin{array}{l}\text { ll patients } \\
\text { eeks } 28 \text { to } \\
\text { nd } 6 \text { days } \\
\text { OMM }\end{array}$ & & & $\begin{array}{l}18 \% \text { of newborns had } \\
\text { chorioamnionitis. } 73 \% \\
\text { of the newborns were } \\
\text { hospitalized for complica-a- } \\
\text { tions of pregnancy, such } \\
\text { as RDS ( } 54.54 \% \text { ). Peri- } \\
\text { natal mortality (2.12\%) } \\
\text { was due to sepsis. } \\
18.5 \% \text { of newborns had } \\
\text { hyperbilirubinemia. RDS } \\
\text { occurred in } 33 \% \text { of rup- } \\
\text { tured membranes that } \\
\text { lasted less than } 24 \text { hours } \\
\text { until delivery, in } 18 \% \text { of } \\
\text { ruptured membranes } \\
\text { that lasted longer than } \\
24 \text { hours until delivery. } \\
\text { The incidence of sepsis } \\
\text { in cases of rupture of the } \\
\text { membranes, with a time } \\
\text { interval of more than } 24 \\
\text { hours until delivery was } \\
36 \% \text {, and in cases of rup- } \\
\text { ture of the membrane, } \\
\text { which had an interval of } \\
\text { less than } 24 \text { hours until } \\
\text { delivery, was } 10 \% \text {. }\end{array}$ \\
\hline 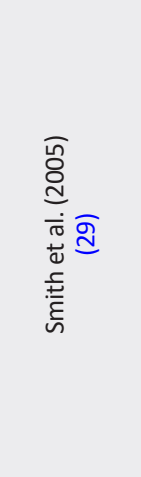 & $\begin{array}{l}\text { Cross-sec- } \\
\text { tional }\end{array}$ & Canada & $\begin{aligned} & 27 \mathrm{mc} \\
& \mathrm{P}\end{aligned}$ & $\begin{array}{l}\text { ers with } \\
M\end{array}$ & & & $\begin{array}{l}\text { Neonatal complica- } \\
\text { tions of PPROM had an } \\
\text { inverse relationship with } \\
\text { gestational age. A total } \\
\text { of } 53 \% \text { of the placenta } \\
\text { were under histopatho- } \\
\text { logic examination after } \\
\text { PPROM, which had } \\
\text { evidence of chorioamnio- } \\
\text { nitis. The increased risk } \\
\text { of chorioamnionitis was } \\
\text { associated with a long } \\
\text { interval from PPROM to } \\
\text { delivery. The prevalence } \\
\text { of PPROM was } 2.3 \% \text {. }\end{array}$ \\
\hline
\end{tabular}

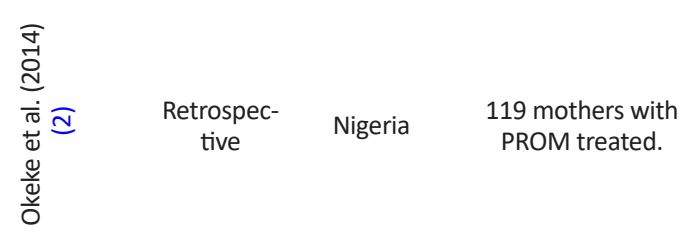

The highest rate of PPROM was in the fertility age range of 26 to 30 years; the lowest rate of PPROM was in the fertility rates of 16 to 20 years and after the age of 41 .
Maternal morbidity was about 20\%.
Perinatal death rate was $7 \%$, and the most important complication of PPROM was infection.

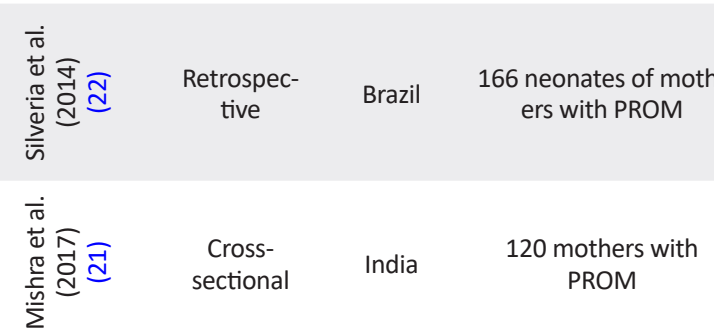

Maternal risk factors were: UTI (31.5\%), chorioamnionitis $(2.4 \%)$ and sexually transmitted infec-

$$
\text { tions }(0.6 \%) \text {. }
$$

Most cases of PROM

occurred in house-

wives aged 20-30

years with a history of PROM. 
control (without the rupture of membrane), and 121 subjects as a group. The results of the study showed no significant relationship between the number of pregnancies, cerclage, and vaginal culture with premature rupture of the membrane (18).

In a study of the historical cohort of Al Riyami et al. (2013), 44 females with preterm premature rupture of the membrane were surveyed for risk factors associated with multiple maternal complications as well as adverse outcomes among Omani females. The results of the study showed that the most important risk factor was the history of infection in 24 of the study subjects. Also, there was no significant relationship between gestational age, parity, maternal age, maternal BMI, and cesarean section. Infection had a significant role both as a risk factor and in the occurrence of a PROM, which was present in $27 \%$ of the study subjects. In a final conclusion, the researchers stated that the co-infection was high in patients with a very early premature rupture of the membrane (6).

In a case-control study, in order to evaluate the risk factors for premature rupture of the membrane, Maryuni et al. compared 114 mothers with premature rupture of the membrane (case group) with 228 mothers without premature rupture of the membrane (control group). According to multivariate analysis, education was the most important risk factor for PROM (19).

In a case-control study, Doody et al. (1997) examined the risk factors of PROM in people with a history of PROM. In their study, 208 females were enrolled as the case group (females with history of sequential PROM) and 848 females as the control group (females with a single PROM history). PPROM recurrence was associated with parity 2 or more (4.3 times). The highest incidence of recurrence of PROM (PROM term or PPROM) was associated with a non-white race (1.9 times) and parity 2 or more (2 times) (20).

Mishra et al. (2017) studied the risk factors of PROM in India. They studied 120 patients with PROM. The cause of most PROM cases was unclear but associated with the history of PROM. Most cases of PROM occurred in housewives aged 20 to 30 years old (21).

\subsection{Articles on the delivery outcomes of PROM ( 1 article)}

Okeke et al. conducted a retrospective study of the prevalence and management of PPROM outcomes in Nigeria. This study was conducted on 119 females treated with PROM. The prevalence of PPROM was $3.3 \%$ and perinatal death was $7 \%$. Maternal morbidity was about $20 \%(2)$.

\subsection{Articles on neonatal outcomes of PROM (1 article)}

Silveria et al. conducted a retrospective descriptive study in Brazil on 166 neonates of mothers with PROM for neonatal outcomes. The results of the study showed a significant relationship between prematurity and long intervals from rupture of the membranes to labor. It was found that gestational age was essentially important for clinical management and predictive evaluation of perinatal outcomes, since the major health problem associated with PROM was prematurity (22).

\subsection{Combination of risk factors, maternal and neonatal outcomes of PROM (9 articles)}

In the study by Boskabadi et al. the frequency of maternal risk factors for prolonged rupture of membrane was investigated. A total of 309 neonates were examined for prolonged rupture of membrane (more than 18 hours before labor). Maternal risk factors included diabetes (12.7\%), hypertension (9.5\%), smoking (8.9\%), history of premature rupture of membrane (8.9\%), urinary tract infection (7.2\%), thyroid disorders (5\%), history of preterm delivery $(4.4 \%)$, and cerclage (3.8\%) (23). Neonatal problems in this study included jaundice, infections, RDS, and asphyxiation, respectively. The common infectious diseases of the neonates with PROM included clinical infection, sepsis, and meningitis, respectively (23).

Sanginabadi et al. in a cohort study, examined the maternal and neonatal complications of premature rupture of membrane. The research subjects consisted of 50 subjects in the control group (hospital care) and 39 subjects in the case groups (home care). The researchers concluded monitoring mothers at home was not necessary, instead if the patient was admitted to the hospital, the doctor should decide for each patient individually and on the basis of her conditions (24).

Boskabadi et al. in a cross-sectional study, examined the outcomes of infants born to mothers with prolonged rupture of membrane (more than 18 hours). Maternal risk factors, antibiotic use and their effects on neonatal outcomes were evaluated. In this study, newborns were divided into three groups: 1 . Symptomatic neonates within 8 hours after birth; 2 . Mothers with chorioamnionitis; and 3. Asymptomatic neonates. A total of 150 neonates were enrolled in the study. Twelve infants (7.7\%) were infected (meningitis, sepsis, pneumonia), 
101 infants (67\%) were immature, and 88 (58.6\%) had mothers with history of antibiotic use. The most common outcome of PROM was prematurity and related side effects, but infection was the most important corrective complication. Although antibiotic therapy in females with a history of PROM improved the neonatal outcomes by reducing neonate sepsis and respiratory distress syndrome, the incidence of meningitis and pneumonia increased (25).

Linehan et al. developed a descriptive retrospective cohort study of females diagnosed with PROM in the second trimester of pregnancy (14 weeks to 23 weeks and six days). This study aimed at investigating the risks for the mother and the fetus. Out of 44667 deliveries, 42 cases were selected during the five-year study. The prevalence of PPROM in the second trimester of pregnancy was 1 in 1000 pregnancies (26). Yang et al. retrospectively reviewed the maternal and fetal outcomes of 73 single- pregnancies with PROM (16 to 26 weeks). The prevalence of sepsis was $42.1 \%$, stillbirth was $30.1 \%$ and neonatal death was $17.8 \%$, pulmonary hypoplasia was $15.7 \%$, and IVH grade 3 or 4 was $7.9 \%$ (27).

Van der Heyden in a retrospective cohort study in the Netherlands reviewed pregnancy outcomes and prenatal risk factors of PPROM in 305 pregnant mothers between weeks 13 and 27 . The researchers concluded that perinatal mortality in PPROM in less than 27 weeks occurred in half of the cases. And among the babies that remained alive, serious complications developed in about $40 \%$ of cases. Prenatal parameters (low gestational age at PPROM, short interval between PPROM and delivery time, positive vaginal culture, and non-use of antibiotics at admission) could help to predict perinatal mortality (28).

Diraviyam et al. examined the maternal and perinatal effects of PROM in a descriptive study on 141 pre-natal patients between weeks 28 and 36 and six days with PROM in India. The most common cause of perinatal mortality in PPROM was prematurity and complications. In late PPROM, the perinatal outcomes were desirable (17).

Smith et al. conducted a cross-sectional study on the prevalence, management, and outcomes of PROM in Canadian females. They studied in nine academic centers in two-week period. During this time, 1168 births occurred and 27 mothers with PPROM were enrolled; so the prevalence of PPROM was $2.3 \%$ (29). The summary of the articles is presented in Table 1.

\section{Discussion}

Since PROM is one of the main causes of perineal morbidity and mortality (30), the current study aimed at evaluating the risk factors and neonatal and delivery outcomes of PROM. In this regard, 15 articles were selected from the medical databases; four studies investigated maternal risk factors, one study evaluated delivery outcomes and one study investigated the neonatal outcomes of PROM. Most studies in this regard were conducted in Iran (four studies, 26.66\%), and then in the United States (two studies, 13.33\%) and India (two studies, 13.33\%).

High admission of neonates following the occurrence of PROM in the hospitals indicated the problems of neonates on the first days of life, so early and accurate assessment of mothers are recommended in order to reduce neonatal complications (25). On the other hand, PROM increases hospital costs and maternal and neonatal hospitalization time. As a result of a PROM complicated term delivery, the average cost of hospitalization increases by $40 \%$, and hospital costs for birth with PPROM is eight times higher than uncomplicated labors (20).

The gestational age at birth is the main determinant of neonatal weight, neonatal complication, need for resuscitation and survival rate in neonates (31). Maternal age is one of the most important risk factors for the occurrence of PROM. Age below 20 years old is associated with a lack of uterine development, and therefore the risk of a PROM increases (32). In some studies, the age of 30 years old and above is considered to be a risk factor for PROM (6).

Maternal education plays an important role in the development of PROM. Mothers with higher education tend to be aware of their health status and their families regarding their nutritional and medical control during pregnancy. Hence, mothers with higher education identify any changes in pregnancy faster (19).

Multiple birth is one of the reasons for PROM. One theory states that the cause of PROM can be excessive uterine stretch, for example in multiple births, polyhydramnios, and inappropriate presentation of the fetus. With a large stretch in the uterus, the infection can enter the amniotic sacs during biomechanical processes, and rupture of the membranes can easily occur. The results of a study showed that more than $53 \%$ of mothers with PROM had cervical length shorter than $35 \mathrm{~mm}$. Hence, short cervical length was considered as one of the effective factors in the occurrence of PROM (18). 
PPROM is important in both aspects of prematurity and infections of newborn, also its complications on the fetus and the neonate are more than that of the mother. Outcomes of PPROM depend on the gestational age and the condition of chorioamnionitis (34). Since most of the neonatal complications of PPROM are because of preterm labor, prolonging the interval between rupture of the membrane and the occurrence of labor by appropriate interventions may reduce prenatal mortality and morbidity (35).

A prolonged rupture of membrane i.e., over 18 hours increases the risk of infection ten times in the baby (25). There is a strong association between PROM and inflammation or intrauterine infection. Moreover, genitourinary tract infection plays an important role in PROM, especially in preterm labors (36).

Asphyxia (40\%) and RDS (28\%) are the most common neonatal complications. The incidence of neonatal complications increases with the duration of PROM. Neonatal complications of PROM include infection (pneumonitis, meningitis and sepsis), pulmonary hypoplasia, deformities of the limbs and body, compression of the umbilical cord and placental abruption (37). In the study by Movahedi et al. sepsis was found in 3\% of neonates with PPROM (38). In a study by Boskabadi et al. (2011), PROM risk factors (40\% of mothers) included history of previous PROM, addiction, and UTI in pregnancy, respectively (25).

The most serious complication of PROM is chorioamnionitis, which is often associated with adverse maternal and neonatal outcomes related to the infection (39). Chorioamnionitis was reported in females with PROM in the study by Medina as $13 \%-60 \%$ (40) and in the study by Boskabadi as $12.7 \%$ (25). Chorioamnionitis, by altering the cervix, causes the loss of integrity of the cervical canal or specific organisms in the vagina that may result in excessive growth of undesirable organisms. Therefore, biochemical changes are made in the fetus membranes and decidua, which ultimately lead to the release of prostaglandin and cytokines and regulate intracellular messaging, which in turn causes the cervix to soften and rupture the membrane. Increasing the activity of the uterus is also common in most cases (41).

In one study, the prevalence of sepsis following PROM was reported $5.4 \%$ to $14 \%$ (42). In the study by Medina, sepsis was found in $5.2 \%$ of the cases following PROM (40). In the study conducted by Boskabadi, clinical sepsis, definitive infection and sepsis were reported in $22 \%$, $8 \%$, and $4 \%$ of neonates, respectively (25). The results of a study showed that the administration of antibiotics in females with PROM reduced the incidence of neonatal sepsis (40). The results of another study comparing the effect of cefotaxime and ampicillin on cases of premature rupture of membrane on infant infections indicated that the risk of infection in infants of mothers with premature rupture of membrane receiving cefotaxime was significantly lower than those of mothers receiving ampicillin (43).

The side effects of the fetus are directly related to the gestational age at the time of the PROM. Preterm PROM increases the premature mortality four times and morbidity of infants three times (44). In the study by Boskabadi et al. (2011), severe asphyxia, pulmonary hypoplasia, sepsis, CNS hemorrhage, and pneumothorax were among the main causes of neonatal death in cases with PROM (25).

With the occurrence of PPROM far from the term, there are certain morbidity and mortality risks for mother and neonate, and this bolds the role of physicians in taking care of a pregnant mother and paying attention to all risk symptoms and making decisions about the timely termination of pregnancy or the continuation of pregnancy (45).

The strength of the current study, to the authors ' best knowledge, was being the first study that investigated the systematic review of risk factors and neonatal and delivery outcomes of PROM. The limitations of the study included the lack of access to all published articles and reports, the lack of accurate and high quality reports, and the applicability of some articles, the lack of clear and identical criteria in studies on PROM, as well as the lack of the same definition of the case group in studies.

\section{Conclusions}

Extensive efforts were made to find out the results of studies on risk factors and maternal, delivery, and neonatal complications of PROM. The obtained studies were different in terms of methodology, methods, risk factors, and outcomes of PROM. PROM is a common problem that may occur at the end of pregnancy. Although prematurity is the most common complication of PROM, other complications such as sepsis, asphyxia, and respiratory distress syndrome may also occur. Timely identification of maternal risk factors and their proper management helps to reduce the incidence and severity of PROM complications. Therefore, it is necessary to conduct more studies to investigate the correlation 
between PROM and other neonatal morbidities such as $B P D$, and pulmonary hemorrhage.

\section{Ethical Considerations}

\section{Compliance with ethical guidelines}

There is no ethical principle to be considered doing this research.

\section{Funding}

This research did not receive any specific grant from funding agencies in the public, commercial, or not-forprofit sectors.

\section{Authors contributions}

The authors contributions is as follows: Conceptualization: Hassan Boskabadi, Maryam Zakerihamidi; Methodology: All authors; Investigation: All authors; Writingoriginal draft: All authors; Writing-review \& editing: All authors; Funding acquisition: All authors; Resources: All authors; and Supervision: Hassan Boskabadi.

\section{Conflict of interest}

The authors declare no conflict of interest.

\section{References}

1. Caughey AB, Robinson JN, Norwitz ER. Contemporary diagnosis and management of preterm premature rupture of membranes. Reviews in Obstetrics and Gynecology. 2008; 1(1):1122.

2. Okeke TC, Enwereji J, Okoro O, Adiri C, Ezugwu E, Agu P. The incidence and management outcome of Preterm Premature Rupture of Membranes (PPROM) in a tertiary Hospital in Nigeria. American Journal of Clinical Medicine Research. 2014; 2(1):14-7.[DOI:10.12691/ajcmr-2-1-4]

3. Al Qaqa K, Al Awaysheh F. Neonatal outcome and prenatal antibiotic treatment in premature rupture of membranes. Pakistan Journal of Medical Sciences. 2005; 21(4):441-4.

4. Gahwagi MM, Busarira MO, Atia M. Premature rupture of membranes characteristics, determinants, and outcomes of in Benghazi, Libya. Open Journal of Obstetrics and Gynecology. 2015; 5(09):494-504. [DOI:10.4236/ojog.2015.59072]

5. Mercer B, Milluzzi C, Collin M. Periviable birth at 20 to 26 weeks of gestation: Proximate causes, previous obstetric history and recurrence risk. American journal of obstetrics and gynecology. 2005; 193(3):1175-80. [DOI:10.1016/j.ajog.2005.05.040]
6. Al Riyami N, Al Ruheili I, Al Shezaw F, Al Khabori M. Extreme preterm premature rupture of membranes: Risk factors and feto maternal outcomes. Oman Medical Journal. 2013; 28(2):10811. [DOI:10.5001/omj.2013.28]

7. Choudhary M, Rathore SB, Chowdhary J, Garg S. Pre and post conception risk factors in PROM. International Journal of Research in Medical Sciences. 2017; 3(10):2594-8.

8. Goldenberg RL, Hauth JC, Andrews WW. Intrauterine infection and preterm delivery. New England Journal of Medicine. 2000 342(20):1500-7. [DOI:10.1056/NEJM200005183422007]

9. ACOG Committee on Practice Bulletins-Obstetrics. ACOG practice bulletin No. 80: Premature rupture of membranes. Clinical management guidelines for obstetrician-gynecologists. Obstetrics \& Gynecology. 2007; 109(4):1007-9.

10. Kaye D. Risk factors for preterm premature rupture of membranes at Mulago Hospital, Kampala. East African Medical Journal. 2001; 78(2):65-9. [DOI:10.4314/eamj.v78i2.9090]

11. Khadijah S, Santoso I, Qana'ah S. Faktor-faktor yang berhubungan dengan kejadian ketuban pecah dini di rsud dr. H. Moch Ansari Saleh Banjarmasin 2015. Dinamika Kesehatan Jurnal Kebidanan Dan Keperawatan. 2016; 7(1):11-20.

12. Dars S, Malik S, Samreen I, Kazi RA. Maternal morbidity and perinatal outcome in preterm premature rupture of membranes before 37 weeks gestation. Pakistan Journal of Medical Sciences. 2014; 30(3):626-9.

13. Lee T, Silver H. Etiology and epidemiology of preterm premature rupture of the membranes. Clinics in Perinatology. 2001; 2 8(4):721-34. [DOI:10.1016/S0095-5108(03)00073-3]

14. Shahin M, Raslan H. Comparative study of three amniotic fluid markers in premature rupture of membranes: Prolactin beta subunit of human chorionic gonadotropin, and alphafetoprotein. Gynecologic and Obstetric Investigation. 2007; 63(4):195-9. [DOI:10.1159/000097844]

15. Borna S, Borna H, Hantoushzadeh S. Perinatal outcome in preterm premature rupture of membranes with Amniotic fluid index<5 (AFI<5). BMC Pregnancy and Childbirth. 2004; 4(1):15. [DOI:10.1186/1471-2393-4-15]

16. Creasy RK, Resnik R, lams JD. Maternal-fetal medicine: Principles and practice. Houston, Texas: Gulf Professional Publishing; 2004.

17. Diraviyam J. Maternal and perinatal outcome in preterm premature rupture of membranes. International Journal of Reproduction, Contraception, Obstetrics and Gynecology. 2017; 6(6):2498-502. [DOI:10.18203/2320-1770.ijrcog20172339]

18. Saremi A, Mosadeq H, Alijani L, Mashhadi khan M. Materna risk factors of PROM after 37 weeks of pregnancy. Sarem Journal of Medicine. 2012; 1(4):9-14.

19. Maryuni M, Kurniasih D. Risk factors of premature rupture of membrane. Kesmas: National Public Health Journal. 2017; 11(3):133-7. [DOI:10.21109/kesmas.v11i3.1153] 
20. Doody D, Patterson M, Voigt L, Mueller B. Risk factors for the recurrence of premature rupture of the membranes. Paediatric and Perinatal Epidemiology. 1997; 11(S1):96-106. [DOI:10.1046/j.1365-3016.11.s1.2.x]

21. Mishra S, Joshi M. Premature rupture of membrane- risk factors: A clinical study. Intrnational Journal of Contemporary Medical Research. 2017; 4(1):146-8.

22. Silveira ML, Caminha NdO, Sousa RAd, Pessoa SMF, Gurgel EdPP, Cavalcante DMP. Neonatal outcome in pregnancies that presented premature rupture of membranes. Northeast Network Nursing Journal. 2014; 15(3):491-9.

23. Boskabadi H, Zakeri Hamidi M, Maamouri G, Najafi A. Frequency of maternal risk factors and neonatal complications of premature rupture of membranes. Journal of Babol University of Medical Sciences. 2016; 18(10):32-9.

24. Sanginabadi M, Seifrabie MA. A comparative evaluation of maternal \& neonatal complications in women between outpatients \& inpatients with preterm premature rupture of the membranes. Scientific Journal of Hamadan Nursing \& Midwifery Faculty. 2014; 22(2):26-32.

25. Boskabadi H, Maamouri G, Mafinejad S. Neonatal complications related with prolonged rupture of membranes. Macedonian Journal of Medical Sciences. 2011; 4(1):93-8.

26. Linehan LA, Walsh J, Morris A, Kenny L, O'Donoghue K, Dempsey $E$, et al. Neonatal and maternal outcomes following midtrimester preterm premature rupture of the membranes: A retrospective cohort study. BMC Pregnancy and Childbirth. 2016; 16(1):25. [DOI:10.1186/s12884-016-0813-3]

27. Yang LC, Taylor DR, Kaufman HH, Hume R, Calhoun B. Maternal and fetal outcomes of spontaneous preterm premature rupture of membranes. The Journal of the American Osteopathic Association. 2004; 104(12):537-42.

28. van der Heyden JL, van der Ham DP, van Kuijk S, Notten KJ, Janssen T, Nijhuis JG, et al. Outcome of pregnancies with preterm prelabor rupture of membranes before 27 weeks' gestation: A retrospective cohort study. European Journal of Obstetrics \& Gynecology and Reproductive Biology. 2013; 170(1):125-30. [DOI:10.1016/j.ejogrb.2013.06.012]

29. Smith GN, Rafuse C, Anand N, Brennan B, Connors G, Crane $\mathrm{J}$, et al. Prevalence, management, and outcomes of preterm prelabour rupture of the membranes of women in Canada. Journal of Obstetrics and Gynaecology Canada. 2005; 27(6):547-53. [DOI:10.1016/S1701-2163(16)30711-3]

30. Heffner $L$, Sherman CB, Speizer FE, Weiss S. Clinical and environmental predictors of preterm labor. Obstetrics and Gynecology. 1993; 81(5(Pt 1)):750-7.

31. Chakraborty B, Mandal T, Chakraborty S. Outcome of prelabor rupture of membranes in a tertiary care center in west Bengal. Indian Journal of Clinical Practice. 2013; 24(7):657-62.

32. Nugroho T, Postpartum P. [Obstetrics textbook (Indonesian)]. Yogyakarta: Nuha Medika; 2010.
33. Prawirohardjo S. Ilmu kebidanan. Jakarta: Yayasan bina pustaka sarwono prawirohardjo; 2008.

34. Danforth DN, Gibbs RS. Danforth's obstetrics and gynecology. Philadelphia, Pennsylvania: Lippincott Williams \& Wilkins; 2008.

35. Magwali T, Chipato T, Majoko F, Rusakaniko S, Mujaji C. Prophylactic augmentin in prelabor preterm rupture of the membranes. International Journal of Gynecology \& Obstetrics. 1999; 65(3):261-5. [DOI:10.1016/S0020-7292(99)00036-3]

36. Romero R, Chaiworapongsa T, Espinoza J. Micronutrients and intrauterine infection, preterm birth and the fetal inflammatory response syndrome. The Journal of Nutrition. 2003; 133(5):1668S-73S. [DOI:10.1093/jn/133.5.1668S]

37. Shrestha SR, Sharma P. Fetal outcome of pre-labor rupture of membranes. Nepal Journal of Obstetrics and Gynaecology. 2006; 1(2):19-24.

38. Movahedi M, Rezaie M, Taefnia AM. Maternal and fetal outcomes of preterm premature rupture of membrane. Journal of Isfahan Medical School. 2013; 30(216):75-6.

39. Gregg AR. Introduction to premature rupture of membranes. Obstetrics and Gynecology Clinics of North America. 1992; 19(2):241-9.

40. Medina TM, Hill DA. Preterm premature rupture of membranes: Diagnosis and management. American Family Physician. 2006; 73(4):659-64.

41. Parry E. Managing PROM and PPROM. Obstetrics \& Gynecology. 2006; 8(4):35-8.

42. Mercer BM, Goldenberg RL, Das AF, Thurnau GR, Bendon RW, Miodovnik $\mathrm{M}$, et al. What we have learned regarding antibiotic therapy for the reduction of infant morbidity after preterm premature rupture of the membranes. Seminars in Perinatology. 2003; 27(3):217-30.

43. Boskabadi H, Saghafi N, Najafi A. Comparing the efficacy of cefotaxime and ampicillin on neonatal infection after premature rupture of membranes. The Iranian Journal of Obstetrics, Gynecology and Infertility. 2014; 17(93):1-9.

44. Uhm S, Alderdice F, Chambers B, Gyte G, Gale C, Duley L, et al. PPO. 23 Top 15 research priorities for preterm birth with clinicians and service users' involvement-outcomes from a James Lind Alliance priority setting partnership. Archives of Disease in Childhood-Fetal and Neonatal Edition. 2014; 99(Suppl 1):A158.

45. Weissmann Brenner A, O'Reilly Green C, Ferber A, Divon MY. Values of amniotic fluid index in cases of preterm premature rupture of membranes. Journal of Perinatal Medicine. 2009; 37(3):232-5. [DOI:10.1515/JPM.2009.078] 
This Page Intentionally Left Blank 